Working Paper No. 653, 2005

\title{
Promoting Entrepreneurship in the Welfare State
}

by Magnus Henrekson and Jesper Roine

IUI, The Research Institute of Industrial Economics

P.O. Box 55665

SE-102 15 Stockholm

Sweden 


\title{
Promoting Entrepreneurship in the Welfare State*
}

\author{
by \\ Magnus Henrekson ${ }^{1}$ and Jesper Roine ${ }^{2}$
}

April 9, 2006

\begin{abstract}
Entrepreneurship is largely ignored, or treated in a highly simplified way, in endogenous growth theory. Still, it is now widely recognized that the supply of entrepreneurial talent is likely to be important for economic growth, innovation, and job creation. In this study we provide an indepth examination of how the supply of productive entrepreneurship is likely to be affected by the kind of tax and welfare arrangements that may prevail in a mature welfare state. Sweden, allegedly the most extensive of all welfare states, is the object of the empirical analysis. It is argued that the Swedish welfare state early on chose a specific "Swedish Model" of trying to combine ambitious welfare programs and a high tax burden with good opportunities for economic growth. This particular view rested heavily on the assumption that innovative activity was best performed in large established firms and that entry of new firms was less important. Consequently, policy and institutions were geared to promoting certain types of activities, which could deliver growth if scale economies are important and intrapreneurship can substitute for entrepreneurship. However, in an environment where entry, exit and turnover of firms are important for growth, and where scale-economies are less important, this kind of model may be more problematic. Both aggregate economic performance and data on firm growth and direct measures of entrepreneurial activity are broadly consistent with the identified structure of payoffs. A number of measures that can be implemented to strengthen entrepreneurial incentives within extensive welfare states are discussed, but the fact still remains that an entrepreneurial culture and a welfare state seem very remotely related. As a result, the respective cultures are unlikely to be promoted by a similar set of institutions.
\end{abstract}

JEL Classification: M13; J20; H30; O12.

Keywords: Economic growth; Entrepreneurship; Innovation; Swedish model; Welfare state.

$\begin{array}{ll}{ }^{1} \text { Research Institute of Industrial Economics } & \begin{array}{l}{ }^{2} \text { Department of Economics } \\ \text { Stockholm School of Economics }\end{array} \\ \text { P.O. Box 55665 } & \text { P.O. Box 6501 } \\ \text { SE-102 15 Stockholm } & \text { SE-113 83 Stockholm } \\ \text { Sweden } & \text { SWEDEN } \\ \text { Phone: +46-8-665 } 4501 & \text { Phone: +46-8-73690 } 00 \\ \text { Fax: +46-8-66545 } 99 & \text { Fax: +46-8-31 32 07 } \\ \text { e-mail: Magnus.Henrekson@iui.se } & \text { e-mail: Jesper.Roine@hhs.se } \\ \text { Homepage: www.hhs.se/personal/henrekson } & \text { Homepage: www.hhs.se/personal/roine }\end{array}$

\footnotetext{
* Both authors gratefully acknowledge financial support from the Jan Wallander and Tom Hedelius Research Foundation.
} 


\section{Introduction}

Over the past decades endogenous growth theory has developed models that come closer to making explicit what drives long-term economic development. More specifically, explicit incentives for innovation have been included so as to explain why individuals would engage in creating new technologies and better ways of producing goods and services (see Barro and Sala-i-Martin 1995, Aghion and Howitt 1998). However, the actual agents of change, the entrepreneurs, are still defined rather narrowly and theory cannot be said to capture the wideranging and complex functions suggested outside mainstream economics (see for example Glancey and McQuaid 2000, Swedberg 2000, and Bianchi and Henrekson 2005).

Common for theories of endogenous growth are that they stress (expected) pay-offs from innovation or more generally the gains from activities which improve production and organization. Consequently, taxes and benefits which reduce incentives for engaging in such activities, or policies which decrease their return should be expected to reduce growth. It is commonly thought that the welfare state is characterized by large marginal tax wedges, reduced incentives to save and accumulate capital, and policies which discourage innovation in general. If this is the case, the welfare state should be expected to reduce innovation and consequently growth. However, it is possible that the disincentive effects from taxes are countered by spending the money on growth-enhancing activities such as schooling, infrastructure, or well functioning institutions. It is also possible - as has been pointed out by e.g. Steinmo 1993 and Lindert 2002 - that taxes in a welfare state can be raised in ways which are more pro-growth and less progressive than is typically imagined. In short, there is no simple theoretical relation between high taxes and a large public sector, and negative effects on economic performance of a country. This mixed view seems to be supported by the empirical literature as well. ${ }^{1}$

This, however, does not imply that the welfare state has no effect on economic performance. On the contrary, the fact that a welfare state almost by definition reaches into more areas of

\footnotetext{
${ }^{1}$ Studies which find negative coefficients on "government consumption" in cross-country growth regressions are for example Easterly and Rebelo (1993), Barro (1997). Fölster and Henrekson (2001) also find negative growth effect from a large public sector. However, Slemrod (1995), Mendoza, Milesi-Ferretti and Asea (1997), and Agell, Lindh and Ohlsson (1997) find no clear costs from social spending. In an overview Temple (1999) concludes that there seems to be no convincing evidence that growth is harmed by having a large public sector.
} 
the lives of its citizens also means that it, to a larger extent than a smaller state, shapes "the rules of the game in society” (North 1990, p. 3). The ultimate questions about the impact of the welfare state on economic growth therefore concern the particular incentive structure which results in the welfare state, and to what extent this forms the set of "appropriate institutions” for a given economy. ${ }^{2}$

This chapter addresses a specific subset of questions concerning the interrelations between endogenous growth theory, the welfare state and entrepreneurship. The purpose is to examine, in an exploratory fashion, how the supply of entrepreneurship - and to a lesser extent its distribution across activities - is likely to be affected by the kind of tax and welfare arrangements that prevail in a typical mature welfare state. In particular, we will stress that it is not simply a question of high taxation or large public programs, as their undisputed negative effects can in principal be countered by positive ones, but rather we will focus on the particular incentives created within the system.

Given that Sweden probably has the most extensive welfare state of all countries (Lindbeck 1997) the country offers a "laboratory", or testing ground, for such an examination. We will argue that the Swedish welfare state, through attempting to combine high taxation and the creation of large public programs with sustained incentives for growth, created a particular incentive structure in which long-term economic progress depends heavily on the success of established large companies. A key assumption for this view - largely inspired by Schumpeter 1942 and later advanced by e.g. Galbraith 1956 - was the idea that innovative activity was best performed within these large firms while the role of individual entrepreneurs and entry of new firms was considered less important.

Our analysis is greatly inspired by Baumol's (1990) study, but since "the structure of payoffs" for entrepreneurship is examined for a modern welfare state both the institutional analysis and the relative performance measures are more precise than in Baumol's broad historical

\footnotetext{
2 The term “appropriate institutions” was coined by Gerschenkron (1962) and has recently received renewed attention in e.g. Acemoglu, Aghion and Zillibotti (2003), and others. They focus on differences in what constitutes good policy depending on a country's "distance to the technological frontier”. We will use it in a broader sense where institutions may be "appropriate" with respect to a number of other aspects of the economy such as distribution of firms in different industries, the size of these firms, etc. But more importantly we will stress that policies which were initially "appropriate" may persist due to vested interests even after exogenous changes (or catch-up to the frontier) have made these policies "inappropriate".
} 
comparisons. Similar studies are needed for other national settings in order to find out the degree to which the findings in this paper have general validity.

The paper is organized as follows. In Section 2 entrepreneurship is defined more precisely and some useful distinctions are made. We also discuss why entrepreneurship is likely to be particularly important for economic development in a modern economy. In Section 3 the modern welfare state is characterized, and more specifically its implementation in Sweden is outlined with regard to aspects that are relevant from an entrepreneurial perspective. Section 4 outlines a political economy theory of the Swedish Model as a compromise between the large established firms and the representatives of workers which lead to the combination of a high average tax rate, a large public sector, but with relatively low tax on capital and relatively favorable conditions for certain types of industries and business entities. This section gives a number of broad predictions which will be followed up in the remaining sections. In Section 5 we look in more detail at what kind of policies this lead to, while we in Section 6 study to what extent the empirical evidence regarding entrepreneurial activity in Sweden is consistent with what may be predicted from the incentive structure. Section 7 concludes.

\section{Defining entrepreneurship and its links to economic growth}

The entrepreneur and entrepreneurship are elusive entities. In the literature one can find at least 13 distinct themes developed around these concepts (Hébert and Link 1989). The most influential view is probably the one proposed by Schumpeter $(1934,1942)$, who saw the entrepreneur as somebody who caused disequilibrium by introducing new technologies (“creative destruction”). Kirzner (1973), on the other hand, emphasizes the role of pushing the economy back towards equilibrium by exploiting previously unperceived opportunities to reach the production possibility frontier. A third influential view was originally proposed by Knight (1921), who sees entrepreneurs as agents who receive a rate of return for bearing what he dubbed "genuine uncertainty", i.e. non-calculable risk.

In the context of this paper these subtleties are of less importance, and to capture the most important mechanisms we will define entrepreneurship, in line with Wennekers and Thurik (1999), as the ability and willingness of individuals, both on their own and within organizations to: (i) perceive and create new economic opportunities; (ii) introduce their ideas in the market, in the face of uncertainty and other obstacles, by making decisions on location, 
form and the use of resources and institutions; and (iii) compete with others for a share of that market.

Thus, in order for an activity to be defined as entrepreneurial it needs to be novel at least in some sense, but whether it is novel because it applies new knowledge or uses existing knowledge in new ways does not matter. There must also be an ambition to grow. As a result, one cannot define entrepreneurship as self-employment or firm formation per se. A person may be entrepreneurial both in his/her role as business owner/self-employed or as an employee (intrapreneur).

Baumol (1990) and Murphy, Shleifer and Vishny (1991) specifically deal with the effect of institutions/the social payoff structure on the distribution of entrepreneurship between productive and unproductive/destructive activities. Baumol assumes that the supply of entrepreneurship, i.e. the application of entrepreneurial talent, is roughly a constant, while its distribution between productive and unproductive activities is affected by the social payoff structure. This assumption is unnecessarily restrictive; there are a priori reasons to assume that the incentive structure will affect both the total supply of entrepreneurial talent and its distribution across activities that are more or less socially productive.

Baumol's broad historical analysis makes clear that the factors that "forge the structure of payoffs" for entrepreneurship are many-faceted, but it is also obvious that the incentive structure cannot be characterized in much detail using this historical method. This is of course easier if one chooses to study contemporary institutional contexts.

By the 1930s the idea that economic development from then on would be possible without the entrepreneurial function had gained strength. In particular, Schumpeter argued forcibly in favour of this view in his 1942 classic Capitalism, Socialism and Democracy, where he claimed that by means of modern techniques and modern modes of organization, the innovation process would become increasingly automated. Innovations would no longer be associated with the efforts and brilliance of specific individuals.

The notion that large-scale production and a social order with strong collectivist elements would promote economic development had many advocates at the time. In particular, Galbraith $(1956,1967)$ provided an important rationale for economic policy oriented towards 
large corporations. He argued that in a modern industrial society, innovative activity as well as improvements in current products and production processes could be carried out most efficiently within the realm of the large industrial corporation. Individual efforts, and hence individual incentives, would dwindle in importance, and small firms and entrepreneurs came to be seen as marginal elements in the process of economic development. We will come back to these ideas as they have been of particular importance in the Swedish case.

The long period during which large firms had predominated and small firms had been increasingly marginalized came to an end in the 1970s. Entrepreneurship and small firms experienced a global resurgence (Brock and Evans 1986; Loveman and Sengenberger 1991). Several reasons why this occurred have been suggested:

(i) Technological change in recent decades has resulted in large reductions in transaction costs in the market, fostering increased specialization across firms and sharper focus on each firm's core activity. Outsourcing and corporate downsizing are concrete manifestations of this change (Carlsson 1999; Piore and Sabel 1984).

(ii) Since the 1960s, there has been a sizeable shift away from industries characterized by large firms (manufacturing, extraction, construction) towards service industries where firms and establishments tend to be smaller (see, e.g. Davis, Haltiwanger and Schuh 1996).

(iii) In tandem with increased incomes, consumers have come to demand more differentiated products rather than standardized products suitable for large-scale production and distribution (Piore and Sabel 1984; Carree and Thurik 1999).

(iv) In many cases, large, mature firms cannot introduce genuinely new products and production methods efficiently. In the long run, radically new technology is required to sustain a high growth rate, since firms in other countries at lower income levels will sooner or later imitate current technologies. Large firms often excel in increasing productivity in the manufacture of existing products, while totally new products are often produced more efficiently in newly established firms, which have been started with the purpose of producing these very products (Baldwin and Johnson 1999; Audretsch 1995).

(v) Small entrepreneurial firms can often act as crucial agents of change. When such firms are motivated to grow they are likely to play a particularly important role in the growth process (Audretsch 1995).

(vi) The small-business sector can function as an inexpensive mechanism for identifying and developing entrepreneurial and managerial talent (Lucas 1978).

The first three mechanisms contribute to an increased tendency for more goods and services to be produced more efficiently in smaller firms and establishments - for structural as well as technological reasons. The last three mechanisms are more dynamic. 
Lately, the importance of entry, exit and turnover of firms - especially in countries close to the technological frontier - has also been stressed, in for example, Aghion and Howitt (2005). In general, the importance of turnover could be seen as the standard Schumpeterian idea that faster growth implies a higher rate of firm turnover as new innovators enter, replacing the former, who exit. However, as noted by Aghion et al. (2005) there are several effects going in opposite directions in terms of how increased competition affects incentives to innovate. On the one hand, stricter competition may reduce growth by reducing post-innovation returns to successful innovators. On the other hand stricter competition induces more "escape competition”, that is incentives for innovation so as to break away from ones competitors through superior technology. They also stress that exit may be positive for productivity growth because it replaces less efficient firms (or inputs) by better ones. The relative size of these effects depends in their framework on the distance to the technological frontier and, more specifically, the closer a country (or a sector) is to the frontier, the more important is entry.

Caree et al. (2002) hypothesize that there ought to be a U-shaped relationship between the degree of entrepreneurial activity and the level of development. Empirically, this is tested by using the rate of self-employment as a proxy for entrepreneurial activity. Some support for the hypothesis is found, in particular for the existence of a downward-sloping segment up to a certain level of income. Wennekers et al. (2005) instead measure entrepreneurial activity as the rate of "nascent entrepreneurship” from the 2002 GEM study (Reynolds et al 2005; see section 6) for 36 countries. In this case the hypothesized U-shape is more evident in the data. Furthermore, Nicoletti and Scarpetta (2003) show that high entry costs and a lower degree of turnover in Europe compared to the US are important for explaining Europe's relatively disappointing growth performance over the past decades, and Sapir et al. (2003) argue that an important reason for the fact that Europe stopped catching up with the US GDP per capita in the mid 1970s has been the failure to switch institutions to ones which promote entry of new firms.

\section{The Mature Welfare State}

In line with Lindbeck (1988) the term "welfare state” is reserved for the array of publicly financed provision or subsidization of personal services, notably for health, education, child 
care and care of the elderly, and for social security systems, transfers and subsidies. The welfare state may of course be defined more broadly by including a number of non-budget or regulatory measures such as price and rent controls and regulations of labor and capital markets, where these measures are intended to benefit particular groups or activities that are considered to be in need of extra support or protection.

The expansion of the welfare state was a salient feature of almost all industrialized countries, in particular during the 1960s and 1970s (Castles 1998; Beck 1981). This tendency was most pronounced in Sweden. In 1960 Sweden was not an exceptional case; the relative size of the public sector was only marginally above the OECD average. ${ }^{3}$ But over the following quarter of a century this situation changed dramatically, and since the late 1960s Sweden has had the largest public sector measured as a share of GDP in the OECD, in particular government consumption as a share of GDP became very high by the 1980s (close to 30 per cent of GDP), which resulted in a very large share of public employment; public sector employment has constituted approximately one third of total employment since about 1980. Total government expenditures as a share of GDP were almost 25 percentage points above the OECD average by the early 1980s. During the latter half of the 1980s the difference diminished somewhat on the expenditure side, but measured from the income side, the public sector remained at a level that was more than 20 percentage points larger as a share of GDP than the OECD average. In the early 1990s the expenditure ratio exploded, largely reflecting the abysmal downturn of the economy. During the latter half of the 1990s the government spending share decreased substantially as a combined effect of austerity measures and the strong recovery after the crisis of the early 1990s. Still, in the first years of the $21^{\text {st }}$ century, the public sector was almost 50 per cent larger than the OECD average.

The Swedish welfare state is so large because ambitions are high both regarding social insurance and public service production. The welfare state cares for its citizens from "cradle to grave” through a large number of schemes (parental leave, child care, medical and dental care, sickness cash benefits, disability pensions, unemployment benefits and public pensions). Income-related, as opposed to flat rate, programs are the rule, which makes the programs costly, and furthermore a number of measures have been introduced over the years that have raised the lower threshold for disposable income. See Forslund (1997) and Aronsson and

\footnotetext{
${ }^{3}$ Going back to 1950 the ratio of total public expenditure to GDP was among the lowest of all industrial countries at roughly 26 per cent, the same level as Switzerland and the United States.
} 
Walker (1997) for an overview of the programs. The consensus view is that the Swedish welfare state has been successful in a number of ways, notably in eliminating poverty and equalizing income, wealth, hours of work and consumption in virtually every respect (over the life cycle, across individuals, across households) (Freeman et al. 1997; Forslund 1997; Lindbeck 1997).

Increasingly, economists recognized the disincentive effects created by a welfare state as extensive as the Swedish one, and these effects were found to be multidimensional, affecting both the choice of work, quantity of market work, intensity of work, investment in human and physical capital, and a host of other dimensions. By the 1990s there were also studies that showed that the overall effect of the welfare systems made it unprofitable to work at all for substantial groups in society - see, e.g. Ds 1994:81 and Ds 1997:73. ${ }^{4}$ It is impossible to give a short summary of the numerous studies, but it is fair to say that overall, economists have emphasized the accumulated disincentive effects of regulations in the capital, product and labor markets and how these have interacted with the disincentive effects emanating from high marginal effects caused by the tax and transfer systems (Agell 1996; Lindbeck 1997). However, surprisingly little attention has been given to the incentive effects of welfare state arrangements on the supply of entrepreneurial effort and its distribution across activities.

\section{The political economics of entrepreneurial policy in the Swedish welfare state}

Above we have discussed aspects of entrepreneurship, endogenous growth theory and some features of the Swedish welfare state. A reoccurring theme has been to point to the importance of the incentives created by policy and in particular that appropriate policies may be highly context specific. However, so far we have said nothing about how policy is chosen. In this section we will first briefly discuss some standard theories of growth where policy is endogenous. We will then discuss some early key ideas about growth policy in the Swedish context and see how the presented political economy ideas could be modified to understand these policies as well as how they can persist, even if they no longer constitute what would be appropriate for enhancing growth.

\footnotetext{
${ }^{4}$ According to one influential welfare state scholar, Gøsta Esping-Andersen (1990), this is in line with the ultimate aim of the Nordic welfare state model, namely, to achieve "the decommodification of labor".
} 
Early endogenous growth theory focused on capital accumulation as the engine of economic growth (Barro and Sala-i-Martin 1995). With this view, economic growth is ultimately a function of individual decisions about capital accumulation, and policy which affects these decisions has an effect on growth. A number of political economy models - i.e. models where policy is determined endogenously through a political process - have been developed to study how, for example, income inequality maps into the choice of broad policies like taxation and redistribution. In models developed by e.g. Alesina and Rodrik (1994) and Persson and Tabellini (1994) high inequality will raise the demand for redistribution, which in turn will lead to high taxes, lowering the returns on investment, thus lowering growth. If, on the other hand, the increased revenue is used to promote infrastructure, to support education or to finance some other policy which may be conducive to accumulation and investment, this could outweigh the negative effect of the tax wedge. ${ }^{5}$ Combining these ideas we get the much debated trade-off between the negative effects from high taxes on investment and savings on the one hand, and the possibility of using tax revenue to promote growth.

A central idea - not present in the above theories of endogenous policy choice - around the time of the expansion of the Swedish welfare state was that high taxes were possible without hurting capital accumulation. As long as taxes did not harm the incentives of those who were thought to be important for the growth-enhancing investments (which would create employment) disincentive effects on others were less of a concern. In particular, detrimental effects on the entrepreneurial function were not thought to be important, since - as already noted in section 2 - the dominant view at the time was that the entrepreneur was waning in importance. The notion that large-scale production and a social order with strong collectivist elements were conducive to economic development had considerable appeal. ${ }^{6}$

Key elements of the Swedish Model are in line with this vision: The large corporations and the public sector as engines of economic development, the perceived unimportance of individual incentives for entrepreneurship, effort and human capital investment, and the claim that not just large-scale production but also innovative activity and renewal could be subordinated to Fordist organizational principles. By the late 1960s it was clear that the ruling

\footnotetext{
5 Some examples of political economy formalizations of such ideas are Saint-Paul and Verdier (1993), Perotti (1996) and Benabou (1996).

${ }^{6}$ We will not go into details of how this vision changed over time. In particular, we will not deal with the (failed) attempt to introduce wage-earner funds. See for example Pontusson (1992) and Henrekson and Jacobsson (2001) for more on this.
} 
party, the Social Democrats, considered small firms and individual entrepreneurs as marginal elements in the process of economic development, and in due course such phenomena were expected to be totally anachronistic (Henrekson and Jakobsson 2001). Johansson and Magnusson (1998) describe how a vision of “capitalism without capitalists” developed. They claim that this vision is crucial, because it constitutes

...the link uniting collectivism and market dynamics. As a result, capitalism can be salvaged without requiring powerful owners or capitalists. Redistribution of income can co-exist with high profits in the most dynamic firms (p. 121).

Could such a policy be an endogenous outcome of a political process? Could there be an outcome where policy is characterized by high redistributive ambitions, a high general tax rate, but relatively favorable conditions for large incumbent firms? The short answer is "yes”. As shown in Roine (2004) it is possible, even in a purely redistributional setting, to have political equilibria characterized by a coalition where those with the very highest initial resources can agree with those with the smallest initial resources to tax the middle group heavily as long as they (the top group) do not pay (full) taxes themselves. ${ }^{7}$ Applying a similar logic to the build up of the Swedish welfare state, the (owners of the) initially large firms could agree with (the representatives of) the workers (i.e. the unions) to have generally high taxes, as long as there were some concessions for them. In fact, such an agreement can even be seen as more beneficial to the large firms than a generally lower tax rate, since high taxes act as a barrier to entry for initially small firms with growth ambitions, but which are too small to be part of the initial coalition. As we shall see in the next section, there are several indications both regarding the structure of taxation and the size distribution of firms over time, which support this view.

A set of institutions which benefits incumbent firms in certain sectors is obviously favorable to them. But is it also possible that this outcome contributes to growth? Again the short answer is "yes". As has already been pointed out above, policies favoring large incumbent

\footnotetext{
${ }^{7}$ In Roine (2004) the setting is one where taxes can be avoided by paying a (large) fixed cost. This results in a situation where only those with high income optimally choose to invest in tax avoidance. If their taxable income (i.e. income after avoidance) is low enough they face a trade-off between taxation and redistribution similar to those with lower incomes, leading to the unusual coalition. A similar logic could be used on the politics of the Swedish welfare state. If there is, for example, a high entry cost for gaining political influence, such influence would only be possible for initially large firms. They could then support high general taxes, as long as they get special treatment (avoidance possibilities). This would lead to a situation with generally high taxes, which hurt investment (and growth) in small firms but has no adverse effects on the large incumbent firms. Indeed, one can even see an additional motive for them to favor the generally high taxes, namely that they act as a barrier of entry on small firms with growth ambitions.
} 
firms can be appropriate if there are important economies of scale making larger firms more efficient in production as well as better suited for innovative activities. Indeed, if this is the case, individual efforts can be seen as a waste of resources as well as entrepreneurial talent and the role of new entrants is small.

What kind of institutions should we expect to evolve as a result of the unusual coalition between the (representatives) of the workers and the initially important firms (the large capital holders)? The theory, of course, says nothing about the exact policies (only that general taxes and redistributive ambitions be high, while there are exemptions for large firms and capital owners) but in terms of incentive structure we could expect institutions favoring:

- Large established firms over smaller, new entrants;

- Industry which is intensive in physical rather than human capital;

- Intrapreneurship over entrepreneurship.

And in terms of outcomes we should expect:

- An industry structure dominated by large and relatively old firms;

- A tax system where investment in physical capital is treated favorably (especially relative to human capital);

- Most innovation taking place within existing corporations;

- A declining share of total taxable income being business income;

- A political rapport between established firms and large capital owners and representatives of the workers and unions. ${ }^{8}$

It is important to emphasize once again, that it is not theoretically possible to conclude that this set of policies is good or bad for growth. In line with Gerschenkron's idea of “appropriate institutions”, policies favoring large corporations could be growth conducive compared to an “incentive-neutral” policy (holding total taxation and redistribution constant). However, if it turns out to be the case that the initially favored firms are not the ones best suited for continued growth and innovation, or that exogenous changes make human-capital intensive

\footnotetext{
${ }^{8}$ See, e.g. Pontusson (1992) and Steinmo (1993) and their extensive references on this topic. As pointed out above we do not go into details of, for example, the differences within the Social Democratic Party regarding this policy.
} 
firms become increasingly important, this kind of policy may be inimical to growth. In particular, if it is the case that entry, turnover and exit of firms and individual entrepreneurship is important, a set of policies favoring large incumbents is not the best for growth.

\section{Welfare state policies and incentives for entrepreneurship}

In this section we will explore in more detail how a number of institutions of the Swedish welfare state affect incentives for entrepreneurship.

\subsection{Taxation of entrepreneurial income}

Income emanating from successful entrepreneurial activity is often capitalized in the form of ownership of equity that appreciates in value. However, over time the Swedish tax code evolved in a way that was highly congruent with a vision of a market economy without individual capitalists and entrepreneurs. This is clear from Table 1 where effective marginal tax rates for different combinations of owners and sources of finance are presented for selected years from 1980 until 2001. Three categories of owners and sources of finance are identified, and the effective marginal tax rate is calculated assuming a pre-tax real rate of return of 10 per cent. A negative number means that the real rate of return is greater after tax than before tax. ${ }^{9}$

The table highlights three important aspects of the Swedish tax system (for further details and additional years, see Davis and Henrekson 1997). First, by 1980 debt financing consistently received an extremely favorable tax treatment relative to new share issues. Second, the taxation of households as owners is much higher than for other categories, and their rate of taxation started to increase sharply in the 1960s, whereas the reverse occurred for insurance companies and tax-exempt institutions. ${ }^{10}$ From some point in the 1960s until the 1991 tax reform, more than 100 per cent of the real rate of return was taxed away for a household

\footnotetext{
${ }^{9}$ The effective real tax rates presented in Table 1 result from a complex interaction of a vast array of different tax rates, accounting and valuation rates, asymmetric effects of inflation etc. This is described in depth in Södersten $(1984,1993)$.

10 Tax-exempt institutions by definition pay no tax on interest receipts, dividends or capital gains. This category includes charities, scientific and cultural foundations, foundations for employee recreation set up by companies, pension funds for supplementary occupational pension schemes, and the National Pension Fund (now seven funds). In terms of industry ownership and control, tax-exempt institutions have a dominant position in Sweden.
} 
buying a newly issued share. Third, tax-exempt institutions benefit from a large tax advantage relative to the other two categories of owners, and this advantage increased strongly during the 1960s and 1970s.

Table 1 Effective Marginal Tax Rates for Different Combinations of Owners and Sources of Finance, 1980, 1991 and 2001 (10\% real pre-tax rate of return at actual inflation rates).

\begin{tabular}{lrrr}
\hline & Debt & $\begin{array}{r}\text { New share } \\
\text { issues }\end{array}$ & $\begin{array}{r}\text { Retained } \\
\text { earnings }\end{array}$ \\
\hline 1980 & & & \\
Households & 58.2 & 136.6 & 51.9 \\
Tax exempt institutions & -83.4 & -11.6 & 11.2 \\
Insurance companies & -54.9 & 38.4 & 28.7 \\
1991 & & & \\
Households & 31.3 & 62.0 & 54.6 \\
Tax exempt institutions & -10.0 & 7.3 & 20.4 \\
Insurance companies & 14.0 & 33.5 & 32.0 \\
2001 & & & \\
Households & & & \\
Tax exempt institutions & $29.7 / 24.7 \dagger$ & $61.0 / 51.0 \dagger$ & $44.1 / 34.1 \dagger$ \\
Insurance companies & -1.4 & 23.6 & 23.6 \\
\hline
\end{tabular}

†Excluding wealth tax; the wealth tax on unlisted shares was abolished in 1992.

Notes: All calculations are based on the actual asset composition in manufacturing. The following inflation rates were used: 1980: 9.4\%, 1991: 5\%, 1994: 3\%, 2001: 3\%. These calculations conform to the general framework developed in King and Fullerton (1984). The average holding period is assumed to be 10 years.

Source: Calculations provided by Jan Södersten; see Södersten $(1984,1993)$.

Households owning a successful business typically faced an even higher tax rate because of the combined effect of wealth and income taxation. Until 1992, wealth tax was levied on 30 per cent of the net worth of a family-owned company. As of the mid-1980s, the maximum wealth tax rate was 3 per cent. Since the wealth tax was not deductible at the company level, funds required to pay the wealth tax were first subject to the personal income tax and the mandatory payroll tax. From around the mid 1960s until the late 1980s the taxation of individually owned firms that could not work with extreme debt-equity ratios was so high that it could be seen as confiscatory in real terms (see Södersten 1984). This spurred the formation of a number of so-called bank-connected investment companies that acquired a large share of the medium-sized family-owned businesses (Petersson 2001). 
This makes clear the extraordinary extent to which the Swedish tax system favored, and still favors, institutional ownership and discouraged direct household ownership of firms, which is a prerequisite for entrepreneurial firms, at least in the early phase of their life cycle.

In order to analyze how the tax system impacts on entrepreneurial behavior it is not sufficient to focus on the taxation of owners of firms. To a large extent the return on entrepreneurial effort is taxed as wage income. First, a large part of income accruing from closely held companies has to be paid out as wage income, since there are severe restrictions on the room for dividends even if the firm is profitable, and the capital gains tax is normally 43 per cent for small closely held firms instead of the regular 30 per cent, since half of the capital gain is taxed as wage income. Second, a great deal of the entrepreneurial function is carried out by employees without an ownership stake in the firm, and the total marginal tax wedge for highincome earners has been high in Sweden throughout the postwar period. Defining the total marginal tax wedge as all taxes paid as a percentage of total labor compensation paid by the employer, the marginal tax wedge for an average wage of an executive (just below the CEO level) went from 50 per cent in 1952 to a peak of 91 per cent in 1979, while the marginal tax wedge for the average white-collar worker peaked at 85 per cent. The comprehensive tax reform in 1991 simplified and lowered the income tax schedule, but as a result of increased local and consumption taxes the total tax wedge was still 75 per cent in the late 1990s for executives and the average white-collar worker alike (Du Rietz 1994; Nordling and Damsgaard 1998). In the early 2000s local taxes have continued to increase while some consumption taxes and property taxes have been lowered. In 2005 the overall tax wedge is still on the order of 75 per cent for these groups.

Furthermore, the use of stock options to encourage and reward intrapreneurship is highly penalized by the tax system, since gains on options are taxed as wage income when the stock options are tied to employment in the firm. Thus, they are subjected both to mandatory social security (33 per cent) and the marginal tax rate. Since the marginal tax rate is roughly 57 per cent this entails a total tax rate of roughly 68 per cent (2005). ${ }^{11}$ In practice, stock options can

\footnotetext{
11 This stands in stark contrast to the US where an employee who accepts stock options can defer the tax liability to the time when the stocks were sold rather than when the options were exercised. In general, there are (i) no tax consequences to the employee upon the grant or the exercise of the option; (ii) the employee is taxed at capital gains rates when the stock acquired upon the exercise of the option is sold after a specified holding period; and (iii) there is no deduction available to the employer. This change in the law shifted the tax risk in the options
} 
therefore not be used as a means to reward entrepreneurial behavior among wealthconstrained individuals. ${ }^{12}$

Finally, it is now widely recognized that venture capital firms can play a crucial role in the development of a small entrepreneurial venture by converting high-risk opportunities to a more acceptable risk level through portfolio diversification, and adding key competencies that the firm may be lacking. This is achieved by means of developing arrangements that align the incentives of the three agents - investors, venture capitalists and entrepreneurial startups (Zider 1998; Gompers and Lerner 2001). However, the above-described tax schedules apply to this industry as well, which means that a highly competent venture capital industry where high-powered incentives can be used to reward investment managers cannot develop in Sweden. ${ }^{13}$

\subsection{Incentives for savings and individual wealth formation}

Welfare state provisions remove a number of savings motives for the individual. As long as unemployment insurance, income-dependent pensions and sick-leave benefits, higher education and highly subsidized health and care services are provided by the government, most of the essential savings motives for the average person disappear. Means-tested schemes such as social assistance may exacerbate this effect at the lower end since it is conditional on the individual not having any assets (Hubbard, Skinner and Zeldes 1995). Moreover, pay-asyou-go pension systems tend to lower national savings and investment compared to funded systems (Feldstein 1996). Thus, in an extensive welfare state system, total savings motives are much reduced. Individual savings rates and average holdings of readily available assets are also very low in Sweden by international comparison - see Table 2 and Pålsson (1998).

\footnotetext{
back to the government, and thus accomplished two things: it increased the potential profit from the stock options and it allowed budget-constrained individuals to sell stocks whenever they chose to do so (Misher 1984). 12 Stock options are also mostly offered to the top level management in large listed firms. In this case, there is more room for arrangements where stock-option gains are taxed largely as capital income, i.e. at 30 per cent rather than 68 per cent.

${ }^{13}$ See Henrekson and Rosenberg (2001) for a fuller exposition of this issue.
} 
Table 2 Household Net Saving as a Share of Disposable Income in Sweden, OECD and OECD Europe, 1960-2004 (per cent).

\begin{tabular}{lrrrrr}
\hline & $1960-69$ & $1970-79$ & $1980-89$ & $1990-97$ & $1998-2004$ \\
\hline Sweden & 6.1 & 4.0 & 1.1 & 5.4 & 2.5 \\
OECD & 9.7 & 12.1 & 11.2 & $9.8 \dagger$ & 6.2 \\
OECD Europe & 12.0 & 13.6 & 11.6 & $10.9 \ddagger$ & 10.9 \\
\hline
\end{tabular}

$\dagger 1990-95 . \ddagger 1990-96$.

Note: Savings in equity pension funds are excluded. OECD Europe 1998-2004 is defined as the Euro-12 countries.

Sources: OECD, Historical Statistics 1960-1980 and 1960-1995; OECD, Economic Outlook, Vol. 65, 1999 and Vol. 77, 2005.

There are numerous research results suggesting that such disincentives to savings and individual wealth accumulation are likely to lower the propensity to supply entrepreneurial effort. The availability of equity financing is a critical factor for both startups and the expansion of existing firms. In general, the riskier the business, the greater the need to rely on equity relative to debt financing and the smaller and newer the firm, the more difficult for outside financiers to assess the viability and profitability of the proposed investment project. Thus, ceteris paribus, small and newly established firms are more dependent on equity financing than large, well-established firms. Low private savings also exacerbate the inherent problem caused by asymmetric information, since wealth-constrained would-be entrepreneurs are unable to signal forcibly to outside investors by means of making sizeable equity infusions of their own.

There is substantial scientific evidence supporting the idea that the individual wealth position has important effects for the probability of becoming an entrepreneur and for the propensity to expand. For example, Lindh and Ohlsson $(1996,1998)$ find that the likelihood of starting a business in Sweden increases significantly among those who receive an inheritance or a lottery gain. They also find that a more unequal wealth distribution covaries positively with the share of self-employed. Similar evidence is found for the US by Holtz-Eakin et al. (1994). This is probably the most well-established finding in the small business economics literature, and there are a host of further studies pointing to the importance of personal assets for the degree to which entrepreneurial talent is exploited, see e.g. Blanchflower and Oswald (1998) and Taylor (2001), and the overview of this literature in Parker (2004, Ch. 5-6). 
In addition to the welfare state reducing the need for savings for precautionary as well as lifecycle reasons, taxation has created additional disincentives. The real rate of taxation on financial savings was extremely high in Sweden for individuals before the 1990/91 tax reform. On interest income it typically exceeded 100 per cent by a wide margin during the 1970s and 80s. The rate of taxation on saving and wealth accumulation remains high. First, the high tax rates on wage income make it hard to save a substantial portion of income that can subsequently be used for equity financing. Second, total taxation on accumulated wealth is high (2005): 30 per cent on the nominal current return, 30 per cent nominal capital gains tax and 1.5 per cent wealth tax on real estate, interest-bearing instruments and prime listed stock.

The combination of low private savings and an extremely even distribution (Lindh and Ohlsson 1998) of these low savings implies that few people are able to raise the requisite equity, either themselves or from their associates, friends or relatives, to realize their business projects.

In recent decades private saving has been encouraged through favorable tax treatment. This concerns both fully tax-deductible pension plans paid individually and supplementary occupational schemes. Through these schemes a person may accumulate substantial wealth. However, following the welfare state logic this is primarily seen as a complement to the income security provided by the government, and hence these funds are by law channeled to traditional financial institutions and the wealth is locked in, at least until age 55, and it cannot be lifted in large chunks. This is likely to reduce the supply of equity financing for potential entrepreneurs and extant small businesses, since pension funds are less suitable for channeling funds to entrepreneurs compared to business angels or venture capital firms. Hence, if the system is designed so that ordinary people are in effect obligated to carry out most of their savings through large collective systems, small business financing will suffer relative to alternative policies and institutional arrangements that allow for greater choice by individuals regarding their savings and investments.

\subsection{Government production of income-elastic services}

No doubt, Schumpeter and Galbraith almost exclusively dealt with the industrial, mostly goods-producing, sector of the economy. However, in Sweden the large-scale production in the manufacturing sector came to be seen as a role model also for central parts of the 
production of highly income-elastic services such as health care, child care, elderly care and education (Rojas 2001). In these cases it was seen as natural that the public sector substituted for the large corporations, and as a result Fordist principles of planning, standardization and large-scale production came to characterize society as a whole - Rojas (2001) speaks of “social Fordism”. This strategy had a profound effect on employment growth across sectors; from 1960 until the mid 1990s all net employment growth in Sweden took place in the local government sector (Rosen 1997).

These publicly produced private services are in many cases highly suitable for production in private and often also small firms. The political decision to produce these services primarily through a public sector monopoly has largely barred this area from both startup activity and the emergence of high-growth firms. Table 3 summarizes the share of private production for the major services that are fully or primarily tax-financed. The private production share is very low in activities like child care, care of the elderly and after-school care, despite the fact that these activities are highly amenable to private, small-firm production. The potential market is huge. The operating costs incurred by local governments for schooling, child care and care of the elderly exceeded 10 per cent of GDP per year in the mid 1990s, and the health care sector is almost as large.

Table 3 Private Sector Production Share for Major Services that are Primarily Publicly Funded, 1996 and 2000 (per cent).

\begin{tabular}{lrr}
\hline Service & 1996 & 2000 \\
\hline Institutional child care (pre-school) & 12.5 & 11.8 \\
Child care in the home (of the & 2.2 & 8.6 \\
professional) & 4.5 & \\
After-school care & 2.4 & 3.9 \\
Compulsory schooling & 1.9 & 4.4 \\
High school & 8.3 & 10.0 \\
Care of the elderly at nursing homes & 5.1 & \\
Care of the elderly in special apartments & 2.6 & \\
Care of the elderly in their own home & 4.3 & \\
Hospital care & 28 & \\
Medical consultations & 10 & \\
Share of doctors privately employed & 24 & \\
Psychiatric wards & 5 & \\
Children's dental care & & \\
\hline
\end{tabular}

Source: Werenfels Röttorp (1998) for 1996 and Jordahl (2002) for 2000. 
Hence, due to the de facto monopolization by the public sector of the production of many income-elastic services vast areas of the economy have remained unexploited as sources of commercial growth. In particular in the health sector, it is easy to imagine how a different organizational mode could have provided a basis for the emergence of new high-growth firms. ${ }^{14}$

\subsection{Household-related services out of reach for entrepreneurial exploitation}

A large percentage of all work, most notably household work, is performed outside the market. Cross-country comparisons of industry-level employment also point to considerable scope for substitution of certain economic activities between the market and nonmarket sectors (Davis and Henrekson 2005). For Sweden, studies indicate that more time is spent on production in the household than in the market. According to the 1997 Service Sector Taxation Report (SOU 1997:17), 7 billion hours were devoted to household work in 1993, while production of goods and public and private services accounted for 5.9 billion hours. Furthermore, paid work not reported to the tax authorities was estimated to represent approximately 10 per cent of the hours worked in the marketplace. The same report also presents evidence that the private service sector is exceptionally small in Sweden compared to other OECD countries. This is particularly the case for wholesale and retail trade, hotels and restaurants and miscellaneous services. In a detailed industry level comparison of Sweden and the US, Davis and Henrekson (2005) demonstrate that relative employment in the US is considerably greater in household-related services, such as repair of durable goods, hotel and restaurant, retail sales, laundry and household work. ${ }^{15}$

In a well-functioning, decentralized market economy, entrepreneurs can be expected to detect and act upon the potential for starting new operations or expand existing ones, thereby creating job opportunities. US trends in recent decades indicate that new jobs net primarily

\footnotetext{
${ }^{14} C f$. the development in the US health sector during the 1990s, where strong competition between health care organizations have led to large cost reductions and efficiency gains, not least because modern information technology is systematically applied (Cutler et al. 2000; Litan and Rivlin 2002).

15 This finding is also consistent with time-use studies reported in Juster and Stafford (1991). There were marked differences between Swedish and US men. US men worked more in the market, while Swedish men performed substantially more household work. In particular, Swedish men were the clear international leaders in home improvement time, averaging 4 hours per week, compared to 2.8 hours for US men and less than 1 hour for Japanese men. Total work time for Swedish and US men were virtually identical (57.9 vs. 57.8 hours). The amount of leisure time was approximately 3 hours longer per week in the US compared to Sweden for both men
} 
arise through the rapid growth of an increasingly differentiated service sector. So why does not Sweden display a similar trend? A fundamental reason emanates from high rates of personal taxation. Personal taxes raise the full price of goods and services. For many goods (e.g., high-tech products like computers), a high price may cause the consumer to forego a purchase, or to buy a lower quality version of the good. This need not be the case with services - high labor taxes often induce the consumer to produce the service himself. This basic insight constitutes an important point of departure in recent work in the theory of optimal taxation. The theoretical results of Jacobsen et al. (2000) and Piggott and Whalley (2001) strongly suggest that the optimal tax structure involves a relatively low tax rate on those market-produced services that could alternatively be produced in the household sector. ${ }^{16}$ High rates of taxation of labor tend to make it more profitable to shift a large share of the service production to the informal economy, in particular into the "do-it-yourself" sector. In the case where the cost of the service consists of labor cost only, one can show that it is profitable to produce the service in the market when (Pålsson 1997; Davis and Henrekson 2005):

$$
\begin{aligned}
& \frac{\text { Buyer's hourly wage before tax }}{\text { Seller's hourly wage before tax }} \cdot \frac{\text { Seller's productivity }}{\text { "do }- \text { it }- \text { yourself"productivity }}> \\
& >\frac{(1+\text { the VAT rate })(1+\text { social security rate })}{1-\text { buyer's marginal tax rate }}
\end{aligned}
$$

Let us call the right-hand side of this expression the tax factor. ${ }^{17}$ The expression describes a fundamental economic relation, which, given wage and productivity differentials, is a crucial determinant of the demarcation line between taxed and untaxed work. Low rates of taxation on labor require smaller wage differentials before tax and/or productivity differences in order to avoid that unpaid work crowds out professional work in cases where unpaid (or black market) work is feasible.

The tax factor in Sweden is in the interval 2.7-4.1 (1997 tax code). In the US the tax factor is generally in the 1.4-1.9 interval. Comparisons between Sweden and the US (California) show that in order for a professional service producer to be competitive vis-à-vis unpaid household production, the professional must have a productivity edge of 170-310 percent in Sweden,

and women. Thus, "Swedish men, compared to US men, have less market work time, more home production time, and less leisure time“ (Juster and Stafford, 1991, p. 498).

16 This result can apply even if these services are complementary to leisure. 
whereas 40-90 per cent is sufficient in the US (in the case of equal market wage).

Alternatively, in the case of equal productivity (e.g., child care) the hourly wage of the buyer must exceed that of the seller by a factor $2.7-4.1$ in Sweden, whereas a factor 1.4-1.9 is sufficient in the US.

As a result, the emergence of a large, efficient service sector competing successfully with unpaid work is less likely in a large welfare state than in countries with lower rates of labor taxation (and higher wage dispersion). As a corollary, an important arena for commercial exploitation and entrepreneurial business development becomes less accessible. Given that more than half of the total volume of work remains commercially unexploited in Sweden this is likely to be of great economic significance, particularly in the long run. When services are provided by professionals, incentives emerge to invest in new knowledge, to develop more effective tools, to develop superior contractual arrangements, to create more flexible organizational structures and so forth. Put simply, higher rates of personal taxation discourage the market provision of goods and services that substitute closely for home-produced services. As a consequence, higher rates of personal taxation reduce the scope for entrepreneurial expansion into new market activities that economize on time use or that supply close substitutes for home-produced services.

\subsection{Incentives for necessity entrepreneurship}

In the empirical literature on the determinants of the supply of entrepreneurship a distinction is often made between pull and push factors (Storey 1994). An individual can either be pulled into entrepreneurship in order to pursue a business opportunity (rather than having a regular job) or he/she can be pushed into it because there is no better choice for work or for making a living. Reynolds et al. (2001, 2005) explicitly distinguish between ”opportunity-based” and "necessity” entrepreneurship in their multi-country effort to measure the rate of entrepreneurial activity. ${ }^{18}$

\footnotetext{
17 The marginal tax rate includes the employee's mandatory contributions to social security.

18 Strictly speaking, necessity entrepreneurship is not consistent with the definition of entrepreneurship given in section 2 . However, what was initially necessity entrepreneurship may in many cases at a later stage become opportunity-based entrepreneurship, when the entrepreneur discovers a growth opportunity in his/her business idea.
} 
The effects of the welfare state discussed so far - taxation of entrepreneurial income and institutional impediments to commercial exploitation in large parts of the service sector - has primarily, at least implicitly, been concerned with the problem that a comprehensive welfare state curbs opportunities for entrepreneurs. But the welfare state also provides ample opportunities for receiving income from the public budget, either as a government employee or as a transfer recipient. Aggregate figures clearly show that these opportunities have increased sharply in Sweden during the postwar period. According to Table 4 there were more than 1.6 persons getting most of their income from the public budget for each person employed in the market sector in 2002. The corresponding figure in 1960 was 0.38 .

Table 4 Number of Tax-Financed and Market-Financed Individuals in Sweden 1960, 1990 and 2002 (millions)

\begin{tabular}{lrrr}
\hline & 1960 & 1990 & 2002 \\
\hline 1. Tax-financed individuals $\dagger$ & 1,143 & 3,887 & 4,021 \\
2. Employed in market-sector $\neq$ & 2,989 & 2,569 & 2,490 \\
Ratio (1/2) & 0.38 & 1.51 & 1.63
\end{tabular}

$†$ The sum of public sector employees, old age pensioners, people on early retirement, paid sick leave, paid parental leave, refugee applicants and people receiving unemployment benefits or participating in labor market programs.

$\ddagger$ Including the self-employed and those working in public utilities and government owned corporations but excluding those on paid sick leave and parental leave.

Source: Lindbeck (1997) for 1960 and 1990, and authors’ own corresponding calculation for 2002.

For the most part, the ambition of the welfare state to equalize outcomes is formally focused on individuals and households. However, there are enormous differences across regions in labor market opportunities, and as a result large interregional differences in employment levels may persist indefinitely, as large sums are transferred from high-employment to lowemployment regions in the form of unemployment benefits, disability pensions, compensation through labor market programs and so forth. Table 5 reports the share of household income consisting of labor income paid by private employers in Swedish municipalities. This share varies from roughly 23 per cent up to two thirds. The country average is slightly below 50 per cent. Thus, these data clearly indicate that the push towards necessity entrepreneurship in lowemployment regions or in a region suffering from a negative shock is very weak. 
The high tax on labor creates difficulties from another standpoint - a decent net wage presupposes high pre-tax earnings. This problem is particularly acute in Sweden, which places a heavy tax burden on the low-income earners. For someone who earns 75 per cent of the average wage of an industrial worker, 61 per cent of the total labor cost consists of taxes and mandatory social security contributions. This is the highest rate among industrialized countries (Norrman 1997).

Table 5 Market Income as a Share of Total Household Income in Swedish Municipalities, 1995 and 1998 (per cent).

\begin{tabular}{lrrlrr}
\hline Top 5 municipalities & 1995 & 1998 & Bottom 5 municipalities & 1995 & 1998 \\
\hline Gnosjö & 64.8 & 68.1 & Pajala & 22.8 & 23.5 \\
Håbo & 61.1 & 63.9 & Boden & 24.7 & 25.4 \\
Täby & 60.2 & 63.9 & Haparanda & 25.7 & 26.7 \\
Gislaved & 60.1 & 62.8 & Övertorneå & 27.5 & 27.4 \\
Sollentuna & 58.4 & 62.5 & Sollefteå & 29.3 & 29.3 \\
Country Average & 45.7 & 48.9 & & & \\
\hline
\end{tabular}

Note: Market income as a share of total income is defined as the share of total household income emanating from labor income paid by private employers. Income from capital is excluded.

Source: SAF (2000).

It seems reasonable to assume that there is a connection between the net wage the individual demands and the minimum income she is guaranteed by the social security system. The net wage demanded corresponds to a certain gross pre-tax wage, the reservation wage. The ingredients that determine the reservation wage are complex and dependent upon a number of circumstances. The social safety nets play an important role in the determination of the reservation wage. Ultimately an individual is entitled to social welfare, which guarantees the household a politically defined minimum standard of living. ${ }^{19}$

Thus, the social safety nets provide a yardstick for measuring an appropriate reservation wage. Although other types of compensation, such as unemployment benefits for the uninsured and housing allowances, may provide less coverage, supplementary assistance can often be obtained up to the level guaranteed by the Social Security Act. A 1994 Swedish Government study (Ds 1994:81) demonstrated that a significant percentage of those who are active or potentially active in the work force, and who live in typical family constellations,

19 See Siebert (1997) for an interesting discussion of the interplay between the reservation wage and the social safety nets from a broader European perspective. 
fell below this basic level. The study concluded that "jobs offering wages below or near what the ultimate social safety net provides are likely to disappear over the long run” (p. 201).

The social safety nets affect what is considered a reasonable wage, the unions' wage claims, and the kinds of businesses that entrepreneurs are willing to start. To the extent that social safety nets in welfare states push up reservation wages, they affect both types of entrepreneurship. They discourage necessity-based entrepreneurship by providing an alternative source of income at a reasonable level and they curb opportunity-based entrepreneurship by pushing up reservation wages so that many activities that are (initially) low-productivity activities are largely barred from entrepreneurial exploitation, since entrepreneurs have low incentives to start businesses that presuppose wages below the level guaranteed by the ultimate safety net.

\subsection{Miscellaneous aspects}

In this subsection a few additional aspects that are likely to impede productive entrepreneurship are dealt with. Although important, they are deemed to be of lesser importance than the factors elaborated upon in subsections 5.1-5.5.

(i) Firms may be eligible for subsidies if they locate in low-income regions or if existing firms expand in those regions. A host of measures including both direct subsidies and tax breaks have been used to this effect. But as shown by Bergström (2000) it appears that in the long-run firms that have received support perform worse than other comparable firms. This kind of support increases the risk that entrepreneurial talent (a scarce resource) is attracted to inherently less productive activities (Murphy et al. 1991). ${ }^{20}$

(ii) In order to equalize income across municipalities and regions a municipal tax-equalization scheme was introduced in 1966 and the redistributive stance of this scheme has been strengthened on several occasions, to the extent that there is virtually no correlation between local/regional government net tax receipts and per capita income in the municipality or county (Fölster 1998; Kommunförbundet, 2000). In fact, it is easy to point to cases where a boom in the local economy will worsen the financial situation of the municipality in question. This equalization of outcomes in yet another dimension has

\footnotetext{
${ }^{20}$ Leonard and Audenrode (1993) find that transfers to ailing industries have negative growth effects.
} 
made it at best economically indifferent for local government officials to promote entrepreneurial activity.

(iii)The Swedish Employment Security Act (LAS) from 1974 gives employees extensive protection against unfair dismissal, and it is hence intended as an additional means to enhance economic security for individuals. The only legal grounds for dismissal are gross misconduct and redundancies. In the latter case, LAS stipulates a "last in - first out principle”. Strict employment security provisions are likely to be more harmful for smaller and potentially fast-growing employers. For many firms - and in particular for firms with a good growth potential in terms of productivity and employment - there is a great need for flexibility both to increase the number of employees in response to rising demand and likewise to be able to rapidly contract when demand falls short of expectations. The road from small to large for a fast-growing firm is far from straight, since the activities of new firms in particular are subject to genuine uncertainty. If, under such circumstances, rules are imposed that reduce the firms' leeway to rapid adjustment, one should expect both a lower willingness to expand in general and that fewer firms, despite a good product or a viable idea, grow from small to large in a short period of time. ${ }^{21}$ In addition, a strictly applied "last in - first out" principle in case of redundancies implies that tenure at the present employer becomes relatively more important for labor security than individual skill and productivity. This fact increases the individual's opportunity cost of changing employers or of leaving a secure salaried job to become an entrepreneur.

\subsection{The emerging picture of policy and its effects on entrepreneurial incentives}

In section 4 we sketched some broad predictions regarding policy in the Swedish welfare state with the starting point that an overriding theme has been the attempt to combine high taxation and ambitious welfare programs with favorable conditions for economic growth. We argued that the particular way of combining these has relied on preferential treatment of large established firms at the expense of individuals and smaller firms, and preferential treatment of physical capital intensive activities compared to human capital intensive ones. In this section we have looked at an array of different policies, which suggests an emerging picture in line with what was predicted in section 4 . In the respective subsections we have shown that the tax system has in various ways favored established large firms over small new ones, institutional ownership over household ownership, as well as physical capital over human capital. The 
emphasis on public provision in certain sectors has also hindered entrepreneurial efforts in these sectors. Overall the incentive structure has been one which both directs entrepreneurial activity and curtails its supply. We now turn to an examination of the outcomes of this particular incentive structure.

\section{Empirical Evidence}

A first, although crude, measure consistent with the described weak incentives for entrepreneurship is the slow aggregate growth of the Swedish economy. Beginning in the mid 1960s the rate of growth began to lag relative to the OECD average, and from 1965 until the mid 1990s, Swedish PPP-adjusted GDP per capita fell by close to 30 percentage points relative to the weighted average of the 23 richest OECD countries (Lindbeck 1997; Henrekson 2001). Although the relative decline has stopped, catching up in relative GDP per capita is only some 2 percentage points since the mid 1990s (OECD, National Accounts, February 2005). ${ }^{22}$ Aggregate private sector employment performance is also very weak. The entire growth in employment after 1950 until the early 2000s took place in the public sector, i.e. no new jobs net were created in the business sector during a fifty-year period despite population growth of more than 20 per cent and a rapid growth in female participation rates (Davidsson and Henrekson 2002). Hence, both the aggregate growth and private sector employment performance is consistent with what one would expect if incentives for entrepreneurship are important.

In our context it is, however, more relevant to examine data that directly speak to the issue of the supply of entrepreneurship. Although one should not equate entrepreneurship to selfemployment, it is still worth noting that from the early 1970s until 1990, Sweden exhibited the lowest ratio of nonagricultural self-employment to civilian employment among all OECD countries (OECD Employment Outlook, July, 1992). The European Observatory for SMEs (1995) reports that Sweden had a lower self-employment rate in 1992 than any of the then 12 member countries of the European Community (EC). The number of self-employed has also decreased in recent decades; comparing 2004 with 1980 and 1994, the number of selfemployed is down by 7 and 5 per cent, respectively (Statistics Sweden, 2005).

\footnotetext{
21 Davis and Henrekson (1997) discuss these issues more fully.

22 Given that the real growth rate has been high compared to the EU and OECD averages since 1994 this may seem puzzling. However, in the same period Swedish terms-of-trade has declined rapidly.
} 
In recent work Roine and Waldenström (2005) have studied top incomes in Sweden over the $20^{\text {th }}$ Century. Of particular interest for the arguments here is the decomposition of income by source. As shown in Figure 1 the share of business income has gone down from close to 20 per cent of an income earner in the top half of the distribution in 1945 to almost nothing in the year 1997. The pattern is virtually identical for the top decile as well as for the top percentile. This is in itself not proof that self-employment has gone down, and even less so that entrepreneurship has decreased over this period. It could be argued that particular tax laws make it profitable to choose different forms of compensation. What is undeniable however, is that this reflects either a decrease of the activity in itself or, at least, the fact that the tax system discourages earning business income to such an extent that it does not show up in the tax statistics (instead it shows up as wage or capital income). Either way it seems clear that policy over this period has discouraged the earning of business income.

Figure 1 The share of total income (excluding capital gains) stemming from business income 1945-1997, for different groups in the income distribution.

\section{Enclosed}

Note: Total income is the sum of wage income, capital income and business income and the figure shows the share of total income which derives from business income for the upper half of the income distribution (P50P100), the top decile (P90-P100) and the top percentile (P99-P100) in the period 1945-1997. See Roine and Waldenström (2005) for series including capital gains and for more on the composition of income over time.

Source: Roine and Waldenström (2005).

More directly comparable estimates of the extent of entrepreneurial activity across countries can be derived from a major collaborative research effort, viz. the Global Entrepreneurship Monitor (GEM; see Reynolds et al. 2001, 2005). Its main goal is to arrive at internationally comparable estimates of the prevalence of "nascent entrepreneurs", i.e. people who are in the process of starting a new business at a given point in time, or who have recently started a business that is still running. In Figure 2 the result of the GEM study for 2004 is displayed. It is clear that the level of nascent entrepreneurs is low in Sweden: roughly 3.7 per cent of the population is engaged in starting a business or running a business founded within the last 42 months. This is the third lowest level among the 19 rich OECD countries participating in the GEM study in 2004. The expected pattern is also found for the prevalence of necessity-based entrepreneurial activity. The lowest activity in this category is experienced in the most extensive welfare states: Sweden, Denmark, Belgium, and the Netherlands. 
Figure 2 Level of Total Entrepreneurial Activity in Rich OECD Countries, 2004.

\section{Enclosed}

Note: The level of total entrepreneurial activity (TEA) is defined as the percentage share of the population aged 18-64 involved in either the start-up phase or managing a new business less than 42 months old.

Source: Reynolds et al. (2005).

There are also a number of indicators of a disproportionate importance of large firms in the Swedish economy. The European Observatory for SMEs (1995) reports that among 16 European countries, Sweden showed the largest value for mean enterprise size in 1990. Average enterprise size was 13 employees in Sweden, more than twice the corresponding average value for the 16 countries. Jagrén (1993) found that relative to GDP, Sweden proved to have twice as many Fortune-500 firms as Japan and the UK, and four times as many as the US and Germany. Even compared to other countries dominated by large firms, such as Finland and South Korea, the number of large firms relative to GDP was substantially greater. Henrekson and Johansson (1999) document that Sweden had the greatest number of large industrial firms (500+ employees) per capita in Europe circa 1990.

Hence, by the late 1980s there were no clear signs of a resurgence of entrepreneurship and small firms, a pattern that began to emerge almost two decades earlier in the US (Loveman and Sengenberger 1991). This picture is also consistent with studies where the growth of firms is examined. Birch and Medoff (1994) maintain that all new jobs net in the US are created in a fairly small number of rapidly growing firms (gazelles). Storey (1994, p. 113) reports that out of 100 small firms in the UK at a certain point in time, the four fastestgrowing firms will generate half of the total number of jobs created by these 100 firms. According to OECD (1998) there is now "general agreement" that the share of jobs created by small firms has increased since the early 1970s in most high-income countries. In contrast, little support for the gazelle hypothesis is found in Sweden (Davidsson et al. 1994, 1996). Instead they find that the contribution of small and medium-sized enterprises to net job creation is largely the result of many small startups. More specifically, Davidsson and Henrekson (2002) and Davidsson and Delmar (2003) study the employment contribution of the 10 per cent fastest-growing firms. Regardless of how they conduct the analysis (unit, period, type of growth) they are unable to find a small group of "elite” firms that collectively account for a substantial share of total job creation. 
A final indication that the policy environment is unfavorable for entrepreneurial ventures is given by the experience of new technology-based firms. Sweden has the highest R\&D expenditure both in total and in the university sector as a share of GDP in the OECD, and Sweden is second only to Israel in terms of publications of scientific and technical articles relative to the size of the economy (OECD 2001). Utterback and Reitberger (1982) made a comprehensive interview study of 60 firms, based on new technology, which had been founded between 1965 and 1974. The 60 firms constituted roughly half of the total population of such firms founded during that period. By 1980 the studied firms together contributed no more than roughly 0.5 per cent of total manufacturing employment. Rickne and Jacobsson (1996) update the Utterback and Reitberger study by following the 53 firms still fulfilling the original selection criteria through 1992. Of the 53 firms only nine had grown to have more than 200 employees in 1992. Taken jointly, the 53 firms employed no more than 3,400 persons in Sweden in 1992.

Table 6 The Distribution of the Stock of New Technology-Based Firms by Size in 1993 (all firms covered by the definition were founded in 1975-93).

\begin{tabular}{lrrr}
\hline Size & $\begin{array}{r}\text { Number of firms } \\
\text { in the category }\end{array}$ & $\begin{array}{r}\text { Number of } \\
\text { employees in the } \\
\text { category }\end{array}$ & $\begin{array}{r}\text { Percentage of } \\
\text { employees }\end{array}$ \\
\hline $3-19$ & 1,022 & 7,702 & 39.5 \\
$20-49$ & 196 & 5,886 & 30.2 \\
$50-99$ & 48 & 3,187 & 16.4 \\
$100-199$ & 15 & 2,009 & 10.3 \\
$200-$ & 3 & 704 & 3.6 \\
Total & 1,284 & 19,488 & 100.0 \\
\hline
\end{tabular}

Source: Rickne and Jacobsson (1999).

Rickne and Jacobsson (1999) study all new technology-based firms founded between 1975 and 1993 (and still in existence in 1993) in Sweden. The main results from their study are summarized in Table 6. The employees of the new technology-based firms accounted for 2.2 per cent of employment in the industries they belonged to (either manufacturing or manufacturing-related services). Thus, their share of total employment was very small and not a single one of the firms had more than 300 employees. 
Given the overall picture conveyed by these studies, it is hardly surprising that not a single one of the 50 largest firms in Sweden in 2000 was founded after 1969 (Figure 3). This may be compared to the very different situation in the US in recent decades, where new and fastgrowing firms have generated not just most of the jobs but also the new industries (Audretsch and Thurik 2000).

Figure 3 Sweden's 50 Largest Private Corporations (Turnover) - Period of Establishment.

\section{Enclosed}

Source: NUTEK and ALMI (2001).

\section{Conclusions}

Are mature welfare states at a disadvantage when it comes to economic growth, innovativeness and employment creation? No doubt, high tax and benefit wedges have disincentive effects, but advocates can also point to likely advantageous effects. In the end, this is of course an empirical question, and it is not yet conclusively settled. In this paper we have systematically explored a number of aspects of one factor that has been largely overlooked in the discussion so far, namely, how a wide array of typical welfare state arrangements may influence the incentives for individuals to supply entrepreneurial effort, and, to a lesser extent, how this effort is distributed across productive and unproductive activities. We have also stressed how some of the ideas underlying the early Swedish welfare state are likely to have pushed incentives in favor of large, established firms and capital intensive production, at the expense of growth of new firms, especially in the service sectors. Such an incentive structure could in theory form the set of "appropriate institutions" for growth if large corporations are superior both in terms of productivity and innovation. However, if it turns out that entry, turnover and exit of firms as well as individual entrepreneurship is important, a set of policies which favor large incumbents is more problematic.

In recent decades evidence suggesting that entrepreneurship is increasingly important for growth and employment creation has accumulated at a rapid rate. Leading scholars of the field speak of "the emergence of the entrepreneurial society" (Acs and Audretsch 2001). But the entrepreneur has been an alien figure in the welfare state. This is not so surprising given that 
the main ideas underlying the (Scandinavian) welfare state model were largely developed during a period when it is was widely believed that the individual entrepreneur was waning in importance as a source of innovation, renewal, employment creation and growth.

Our examination of how key welfare state arrangements in Sweden, allegedly the most mature of all welfare states, have structured payoffs suggests negative effects on the return to entrepreneurial behavior both in relative and absolute terms. A number of channels contributing to this effect have been examined: taxation of entrepreneurial income, muted savings incentives and savings encouraged to take forms that withdraw funds from entrepreneurial ventures, comprehensive government service provision and very high tax rates on labor that bar large parts of the economy from entrepreneurial exploitation. Furthermore, schemes for redistribution across individuals and regions and a high level of minimum standard of living guaranteed by the government renders necessity entrepreneurship unnecessary and strict labor security legislation discourages mobility of individuals across firms and industries.

Performance measures for Sweden in recent decades do not contradict the hypothesis that favorable incentives for entrepreneurship are important for economic performance. In particular, the almost complete lack of new high-growth firms in Sweden is striking, despite recent record levels of $\mathrm{R} \& \mathrm{D}$ spending, and with an industry structure well-suited for taking advantage of the boom in the IT and biotech sectors in the 1990s (Elg 2005). As emphasized by Audretsch (2002) it is imperative that the really promising startups act in an environment where they can grow rapidly, because if scale economies are anything other than negligible, then the new firms have to grow in order to survive. Ultimately, they will have to attain the minimum efficient scale level of output, or they will go out of business. According to our analysis the government has a key role in creating an environment fostering the success and viability of firms, so that good ideas have a maximum chance to get translated into successful commercial ventures attaining their full potential.

So is there scope for changing the incentive structure? In light of our analysis of the endogenous determination of policy some problems clearly stand out. The reliance on large incumbent firms and the public sector as the creators of employment opportunities and economic progress have made them seem indispensable. Their dominance has also turned these groups into powerful lobbyists for a continuation of traditional policies to foster future 
growth. As pointed out by Lindbeck (e.g. 1995) it may be a difficult collective problem to unwind a welfare system in which most individuals have stakes. Similarly, it may be difficult to change industrial policy in a situation where many people have become dependent on the success of the incumbent large firms, and where vested interests have substantial political clout.

Nevertheless, quite a few things can be done that cost fairly little and give strong incentives to individual entrepreneurs:

(i) Ownership taxation can be lowered considerably by removing double taxation and giving more room for closely held firms to pay dividends. Furthermore, capital gains taxation on long-term holdings of firms where the individual takes active part could be abolished (long-term capital gains taxation is in fact zero in the majority of the EU-15 countries). Such measures would send strong signals to existing and potential entrepreneurs, while costing very little in terms of taxes forgone.

(ii) Savings can be "deinstitutionalized" so that large part of the pension wealth becomes available for equity investments in entrepreneurial firms.

(iii)The public sector can implement a strategy for encouraging entrepreneurs to substitute for tax-financed public sector service production. A further step would be to allow service producers to offer additional services on top of what is granted through a tax-financed voucher system, while monitoring that tax-financed services are distributed solidaristically.

(iv)Retention rates can be marginally lowered across the board and qualification criteria can be made more stringent for transfer programs. This would not jeopardize the welfare state, but it would contribute to making entrepreneurship more attractive on the margin.

(v) A more radical measure would be to announce that since the welfare state protects the individual through a number of cushions, the obligations for firms could be eased substantially: more liberal job security mandates, fewer demands on firms to take responsibility for sick leave, rehabilitation programs etc. ${ }^{23}$

(vi)Rights “earned” through tenure with the present employer could be made portable, for instance through a system of severance pay. ${ }^{24}$ After all, labor market inflexibility is an

\footnotetext{
${ }^{23}$ In this respect Denmark differs greatly from Sweden. State provision of income security is at least as generous, while labor security legislation is among the least protective of insiders relative to outsiders in Europe. ${ }^{24}$ Severance pay is common in Italy, where large firms set aside a $13^{\text {th }}$ salary every year, which is paid out upon termination of the job, these arrangements are called TFR (trattamento di fine rapporto). The tax rate is only 10
} 
element inherently inconsistent with the flexibility, nonhierarchical structures, networking and labor mobility across firms distinguishing an entrepreneurial business culture (Saxenian, 1996).

Still, a mature welfare state will almost by definition have a high aggregate tax burden, and this necessarily implies high tax rates on labor and on locally produced services. As a result, it will be difficult to develop the household-related service sector as much as in low-tax countries. Likewise, individual savings incentives will be lower and reservation wages will be pushed up to higher levels by more generous social assistance schemes (relative to average income).

Finally, a continued almost exclusive reliance on taxation for the financing of key services like education, health care, child care and care of the elderly can be expected to become increasingly problematic. These services are highly income-elastic, they suffer from Baumol's Disease (Baumol 1993b), and technological breakthroughs are likely to increase the supply of services in the health sector in the future. As long as private purchasing power is not allowed into these sectors, they risk turning into a tax-financed “cost problem” rather than becoming potential growth industries attracting talented entrepreneurs.

All in all, there seems to be some room for a mature welfare state to reform itself in ways that promote entrepreneurship, while the core of the welfare model remains intact. However, a vibrant entrepreneurial culture and the set of institutions that underpins such a culture seem very remotely related to the welfare state culture and its institutions, perhaps they are even negatively related.

per cent, and allegedly this institution has made it possible for many redundant workers to start their own business. 


\section{References}

Acemoglu, D., Aghion, P. and F. Zilibotti (2003), 'Vertical Integration and Distance to Frontiers', Journal of the European Economic Association, 1(2), 630-38.

Acs, Z. J. and D. B. Audretsch (2001), ‘The Emergence of the Entrepreneurial Society’, Prize lecture, The International Award for Entrepreneurship and Small Business Research, Stockholm, May.

Agell, J. (1996), ‘Why Sweden’s Welfare State Needed Reform’, Economic Journal, 106(459), 1760-1771.

Agell, J., Lindh, T. and H. Ohlsson (1997), 'Growth and the Public Sector: A Critical Review Essay', European Journal of Political Economy, 13(1), 33-52.

Aghion, Phillipe and Peter Howitt (1998), Endogenous Growth Theory, Cambridge, MA: MIT Press.

Aghion, P. and P. Howitt (2005), ‘Appropriate Growth Policy: A Unifying Framework’ 2005 Joseph Schumpeter Lecture delivered at the conference of European Economic Association, August 25, 2005.

Aghion, P., Burgess, R., Redding, S. and F. Zilibotti (2005), 'Entry Liberalization and Inequality in Industrial Performance', Journal of the European Economic Association, Papers and Proceedings, 3(2-3), 201-302.

Alesina, A. and D. Rodrik. (1994), 'Distributive Politics and Economic Growth', Quarterly Journal of Economics, 109(2), 465-490.

Aronsson, Thomas. and James R. Walker (1997), 'The Effects of Sweden's Welfare State on Labor Supply Incentives', in Freeman, Richard B., Topel, Robert and Birgitta Swedenborg (eds) The Welfare State in Transition, Chicago: University of Chicago Press.

Audretsch, David B. (1995), Innovation and Industry Evolution,,Cambridge, MA: MIT Press.

Audretsch, D.B. (2002), 'The Dynamic Role of Small Firms: Evidence from the US’ Small Business Economics, 18(1), 13-40.

Audretsch, D.B. and A. R. Thurik (2000), 'Capitalism and Democracy in the $21^{\text {st }}$ Century: From the Managed to the Entrepreneurial Economy’, Journal of Evolutionary Economics 10(1), 17-34.

Baldwin, John R. and Joanne Johnson (1999), ‘Entry, Innovation and Firm Growth’ in Acs, Zoltan J. (ed.) Are Small Firms Important? Their Role and Impact, Dordrecht: Kluwer.

Barro, Robert J. and Xavier Sala-i-Martin (1995), Economic Growth, New York: McGraw-Hill.

Barro, Robert J. (1997), Determinants of Economic Growth: A Cross Country Empirical Study, Cambridge, MA: MIT Press.

Baumol, W. J. (1990), 'Entrepreneurship: Productive, Unproductive, and Destructive’, Journal of Political Economy, 98(5), 893-921.

Baumol, William J. (1993a), Entrepreneurship, Management and the Structure of Payoffs, Cambridge, MA: MIT Press.

Baumol, W.J. (1993b), 'Health Care, Education and the Cost Disease: A Looming Crisis for Public Choice.', Public Choice, 77(1), 17-28.

Beck, Morris (1981), Government Spending, Trends and Issues, New York: Praeger.

Bénabou, Roland (1996), 'Inequality and Growth’, in Ben Bernanke and Julio Rotemberg (eds) NBER Macroeconomics annual 1996, Cambridge, MA, MIT Press.

Bergström, F. (2000), 'Capital Subsidies and the Performance of Firms’, Small Business Economics, 14(3), 8393.

Bianchi, M. and M. Henrekson (2005), 'Is Neoclassical Economics Still Entrepreneurless?’ Kyklos, 58(3), 353377.

Birch, David L. and James Medoff (1994), ”Gazelles’ in Solmon, Lewis C. and Alec R. Levenson (eds), Labor Markets, Employment Policy and Job Creation, Boulder and London: Westview Press.

Blanchflower, D.G. and A. J. Oswald (1998), 'What Makes an Entrepreneur?’, Journal of Labor Economics, 16(1), 26-60.

Brock, William A. and David S. Evans (1986), The Economics of Small Firms, New York: Holmes \& Meier.

Carlsson, Bengt (1999), 'Small Business, Entrepreneurship, and Industrial Dynamics’, in Acs, Zoltan J. (ed.), Are Small Firms Important? Their Role and Impact, Dordrecht: Kluwer.

Carree, M., van Stel, A., Thurik, A. R and S. Wennekers (2002), 'Economic Development and Business Ownership: An Analysis Using Data of 23 OECD Countries in the Period 1976-1996', Small Business Economics 19(3), 271-290. 
Carree, Martin and A. Roy Thurik, (1999), 'Industrial Structure and Economic Growth’, in Audretsch, David B. and A. Roy Thurik (eds), Innovation, Industry Evolution and Employment, Cambridge, MA: Cambridge University Press.

Castles, Francis G. (1998), Comparative Public Policy. Cheltenham, UK and Brookfield, US: Edward Elgar.

Cutler, D. M., McClellan, M. and J. P. Newhouse (2000), 'How Does Managed Care Do It?', Rand Journal of Economics, 31(3), 526-548.

Davidsson, Per and Frederic Delmar (2003). 'Hunting for New Employment: The Role of High Growth Firms'. in Kirby, D. A. and A. Watson (eds), Small Firms and Economic Development in Developed and Transition Economies: A Reader, Aldershot, UK: Ashgate.

Davidsson, P. and M. Henrekson (2002), 'Institutional Determinants of the Prevalence of Start-ups and HighGrowth Firms: Evidence from Sweden’, Small Business Economics, 19(2), 81-104.

Davidsson, Per, Lindmark, Leif and Christer Olofsson (1994), Dynamiken i svenskt näringsliv, Stockholm: Almqvist \& Wiksell.

Davidsson, Per, Lindmark, Leif and Christer Olofsson (1996), Näringslivsdynamik under 90-talet, Stockholm: NUTEK.

Davis, Steven J., Haltiwanger, John and Scott Schuh (1996), Job Creation and Destruction, Cambridge, MA: MIT Press.

Davis, Steven J. and Magnus Henrekson (1997), 'Industrial Policy, Employer Size and Economic Performance in Sweden', in Freeman, Richard B., Topel, Robert and Birgitta Swedenborg (eds), The Welfare State in Transition, Chicago: University of Chicago Press.

Davis, Steven J. and Magnus Henrekson (2005), 'Tax Effects on Work Activity, Industry Mix and Shadow Economy Size: Evidence from Rich-Country Comparisons’, in Goméz-Salvador, Ramón, Lamo, Ana, Petrongolo, Barbara, Ward, Melanie and Etienne Wasmer (eds), Labour Supply and Incentives to Work in Europe, Cheltenham, UK and Northampton, MA, US: Edward Elgar.

Ds 1994:81, En social försäkring, Report to ESO. Stockholm: Ministry of Finance.

Ds 1997:73, Lönar sig arbete?, Report to ESO. Stockholm: Ministry of Finance.

Du Rietz, Gunnar (1994), Välfärdsstatens finansiering, Stockholm: City University Press.

Easterly, W. and S. Rebelo (1993), 'Fiscal Policy and Economic Growth', Journal of Monetary Economics, 32(10), 417-458.

Elg, Lennart (2005), 'Innovation Policy and Performance in Sweden’, in OECD, Innovation Policy and Performance: A Cross-Country Comparison. OECD: Paris.

European Observatory for SMEs (1995), Third Annual Report 1995, Zoetermeer, the Netherlands: EIM Small Business Research and Consultancy.

Esping-Andersen, Gøsta (1990), The Three Worlds of Welfare Capitalism, Cambridge: Polity.

Feldstein, M. (1996), 'The Missing Piece in Policy Analysis: Social Security Reform', American Economic Review, 86(2), 1-14.

Forslund, Anders (1997), 'The Swedish Model: Past, Present, and Future', in Giersch, H. (ed.), Reforming the Welfare State, Berlin: Springer Verlag.

Fölster, Stefan (1998), Kommuner kan! Kanske!, Stockholm: Expertgruppen för studier i offentlig ekonomi.

Fölster, S. and M. Henrekson (2001), 'Growth Effects of Government Expenditure and Taxation in Rich Countries’, European Economic Review, 45(8), 1501-1520.

Freeman, Richard B., Topel, Robert and Birgitta Swedenborg (eds), (1997), The Welfare State in Transition, Chicago: University of Chicago Press.

Galbraith, John K. (1956), American Capitalism: The Concept of Countervailing Power, Boston: Houghton Mifflin.

Galbraith, John K. (1967), The New Industrial State, London: Hamish Hamilton.

Gerschenkron, Alexander (1962), Economic Backwardness in Historical Perspective Cambridge, MA: Harvard University Press.

Gompers, Paul A. and Joshua Lerner (2001), The Money of Invention: How Venture Capital Creates New Wealth, Cambridge, MA: Harvard University Press.

Glancey, Kevin S. and Ronald W. McQuaid (2000), Entrepreneurial Economics, Palgrave: New York.

Hébert, R. F. and A. N. Link (1989), 'In Search of the Meaning of Entrepreneurship', Small Business Economics, 1(1), 39-49. 
Henrekson, M. (2001), 'Swedish Economic Growth: A Favorable View of Reform', Challenge, 44(4), 38-58

Henrekson, M. and U. Jakobsson (2001), 'Where Schumpeter Was Nearly Right - The Swedish Model and Capitalism, Socialism and Democracy’, Journal of Evolutionary Economics, 11(3), 331-358.

Henrekson, M. and D. Johansson (1999), 'Institutional Effects on the Size Distribution of Firms', Small Business Economics, 12(1), 11-23.

Henrekson, M. and N. Rosenberg (2001), 'Designing Efficient Institutions for Science-Based Entrepreneurship: Lessons from the US and Sweden', Journal of Technology Transfer, 26(3), 207-231.

Holtz-Eakin, D., Joulfaian, D. and H. S. Rosen (1994), 'Sticking It out: Entrepreneurial Survival and Liquidity Constraints', Journal of Political Economy, 102(1), 53-75.

Hubbard, R. G., Skinner, J. and S. P. Zeldes (1995), ”Precautionary Savings and Social Insurance’, Journal of Political Economy, 103(2), 360-399.

Jacobsen, H., Richter, W. F. and P. B. Sørensen (2000), 'Optimal Taxation with Household Production', Oxford Economic Papers, 52(3), 584-594.

Jagrén, Lars (1993), ”De dominerande storföretagen’ in Den långa vägen, Stockholm: The Research Institute of Industrial Economics.

Johansson, Anders L. and Lars Magnusson (1998), LO - andra halvseklet. Fackföreningsrörelsen och samhället, Stockholm: Atlas.

Jordahl, Henrik (2002), Vad har hänt med de enskilda alternativen?, Stockholm: Reforminstitutet.

Juster, F. T. and Stafford, F. P. (1991), ’The Allocation of Time: Empirical Findings, Behavioral Models, and Problems of Measurement', Journal of Economic Literature, 29(2), 471-522.

King, Mervin A. and Don Fullerton (eds), (1984), The Taxation of Income from Capital. A Comparative Study of the United States, the United Kingdom, Sweden and West Germany, Chicago: University of Chicago Press.

Kirchhoff, Bruce A. (1994), Entrepreneurship and Dynamic Capitalism, London: Praeger.

Kirzner, Israel M. (1973), Competition and Entrepreneurship, Chicago: University of Chicago Press.

Kirzner, I. M. (1997), 'Entrepreneurial Discovery and the Competitive Market Process: An Austrian Approach”, Journal of Economic Literature, 35(1), 60-85.

Knight, Frank H. (1921), Risk, Uncertainty and Profit,. New York: Houghton Mifflin.

Kommunförbundet (2000), Utjämning mellan kommunerna - en kort beskrivning av dagens system, Stockholm.

Leonard, J. S and M. A. Audenrode (1993), 'Corporatism Run Amok: Job Stability and Industrial Policy in Belgium and the United States', Economic Policy, No. 17, 356-400.

Lindbeck, A. (1988), 'Consequences of the Advanced Welfare State’, The World Economy, 11(March), 19-37.

Lindbeck, A. (1995), 'Hazardous Welfare-State Dynamics', American Economic Review, Papers and Proceedings, 85(2), 9-15.

Lindbeck, A. (1997), 'The Swedish Experiment', Journal of Economic Literature, 35(3), 1273-1319.

Lindert, P. (2002), 'Why the Welfare State Looks Like a Free Lunch', Mimeo, UC-Davis.

Lindert, Peter (2004), Growing Public: Social Spending and Economic Growth since the Eighteenth Century,. Cambridge: Cambridge University Press.

Lindh, T. and H. Ohlsson (1996), 'Self-Employment and Windfall Gains: Evidence from the Swedish Lottery’, Economic Journal, 106(439), 1515-1526.

Lindh, T. and H. Ohlsson (1998), 'Self-Employment and Wealth Inequality', Review of Income and Wealth, 44(1), 25-42.

Litan, Robert E. and Alice M. Rivlin (2002), Beyond the dot.coms, Washington D.C.: Brookings.

Loveman, G. and W. Sengenberger (1991), ”The Reemergence of Small-Scale Production: An International Comparison’, Small Business Economics, 31(1), 1-37.

Lucas, R. E., Jr. (1978), 'On the Size Distribution of Business Firms’, Bell Journal of Economics, Vol. 9, No. 3, 508-523.

Mendoza, E., Milesi-Ferretti, G. M., and P. Asea (1997), On the ineffectiveness of Tax Policy in Altering LongRun Growth, Journal of Public Economics, 66(1), 99-126.

Misher, N. (1984), ”Tax Consequences of Exercising An Incentive Stock Option with Stock of the Granting Corporation', The Tax Executive, July, 357-363.

Murphy, K. M., Shleifer, A. and R. W. Vishny (1991), ‘The Allocation of Talent: Implications for Growth’, Quarterly Journal of Economics, 106(2), 503-530. 
Nicoletti, G. and S. Scarpetta (2003), 'Regulation, Productivity and Growth', Economic Policy, No. 36, 11-72.

Nordling, D. and N. Damsgaard, (1998), 'Så höga är skatterna 1998', Report 1998:1. Stockholm: Swedish Taxpayers' Association.

Norrman, Erik (1997), Skatterna på arbete i Sverige och omvärlden 1996, Stockholm: Swedish Taxpayers' Association.

North, Douglass C. (1990), Institutions, Institutional Change and Economic Performance, Cambridge: Cambridge University Press.

NUTEK \& ALMI (2001), Tre näringspolitiska utmaningar - Allianser för hållbar tillväxt, Stockholm: NUTEK Förlag.

OECD (1998), Fostering Entrepreneurship, OECD: Paris.

OECD (2001), OECD Science, Technology and Industry Scoreboard 2001, OECD: Paris.

Pålsson, Anne-Marie (1997), 'Taxation and the Market for Domestic Services', in Persson, Inga and Christina Jonung (eds), Economics of the Family and Family Policies, London: Routledge.

Pålsson, A-M. (1998), 'De svenska hushållens sparande och förmögenheter 1986-1996’, Mimeo. Department of Economics. Lund University.

Parker, Simon C. (2004), The Economics of Self-Employment and Entrepreneurship, Cambridge: Cambridge University Press.

Persson, T. and G. Tabellini (1994), 'Is Inequality Harmful for Growth?’, American Economic Review, 84(3), 600-621.

Perotti, R. (1996), 'Growth, Income Distribution, and Democracy: What the Data Say', Journal of Economic Growth, 1(2), 149-88.

Petersson, Tom (2001), 'Promoting Entrepreneurship. Bank-Connected Investment Development Companies in Sweden 1962-1990’, in Henrekson, Magnus, Larssson, Mats and Hans Sjögren (eds), Entrepreneurship in Business and Research. Essays in Honour of Håkan Lindgren. Stockholm: Probus.

Piggott, J. and J. Whalley (2001), 'VAT Base Broadening, Self Supply, and the Informal Sector', American Economic Review, 91(4), 1084-94.

Piore, Michael and Charles Sabel (1984), The Second Industrial Divide, New York: Basic Books.

Pontusson, Jonas (1992), The Limits of Social Democracy - Investment Politics in Sweden, Ithaca and London: Cornell University Press.

Reynolds, P. D. et al. (2001), Global Entrepreneurship Monitor. 2000 Executive Report, Wellesley, MA/London/Kansas City: Babson College, London Business School and Kauffman Center for Entrepreneurial Leadership.

Reynolds, P. D., et al. (2005), Global Entrepreneurship Monitor. 2004 Executive Report. Wellesley, MA/London/Kansas City: Babson College, London Business School and Kauffman Center for Entrepreneurial Leadership.

Rickne, A. and S. Jacobsson (1996), 'New Technology-Based Firms - An Exploratory Study of Technology Exploitation and Industrial Renewal', International Journal of Technology Management, 11(3/4), 238-257.

Rickne, A. and S. Jacobsson (1999), 'New Technology-based Firms in Sweden - A Study of their Direct Impact on Industrial Renewal', Economics of Innovation and New Technology, 8(2), 197-223.

Roine, J. and Waldenström, D. (2005), 'Top Incomes in Sweden over the Twentieth Century', SSE/EFI Working Paper Series in Economics and Finance No. 602, Stockholm School of Economics.

Roine, J. (2006), 'The Political Economics of not Paying Taxes', Public Choice, 126(1-2), 107-134.

Rojas, Mauricio (2001), Beyond the Welfare State: Sweden and the Quest for a Post-Industrial Welfare Model, Stockholm: Timbro.

Rosen, Sherwin (1997), 'Public Employment and the Welfare State in Sweden', in Freeman, Richard B., Topel, Robert and Birgitta Swedenborg (eds), The Welfare State in Transition, Chicago: University of Chicago Press.

SAF (2000), Strukturrapport 2000. Ett gyllene tillfälle!, Stockholm: SAF.

Saint-Paul, G. and Verdier, T. (1993), 'Education, Democracy and Growth', Journal of Development Economics, 42(2), 399-407.

Sapir, André, et al. (2003) An Agenda for a Growing Europe, Oxford: Oxford University Press.

Saxenian, AnnaLee (1996), Regional Advantage. Culture and Competition in Silicon Valley and Route 128, Cambridge, MA: Harvard University Press. 
Schumpeter, Joseph A. (1934), The Theory of Economic Development, Cambridge, MA: Harvard University Press.

Schumpeter, Joseph A. (1942), Capitalism, Socialism and Democracy, New York: George Allen \& Unwin.

Siebert, H. (1997), 'Labor Market Rigidities: At the Root of Unemployment in Europe', Journal of Economic Perspectives, 11(4), 37-56.

Slemrod, J. (1995), 'What Do Cross-Country Studies Teach about Government Involvement, Prosperity, and Economic Growth?', Brookings Papers on Economic Activity, 2, 373-431.

SOU 1997:17, Skatter, Tjänster och Sysselsättning, Stockholm: Ministry of Finance.

van Stel, A., Carree, M. and A. R. Thurik (2005), 'Economic Development and Business Ownership: An Analysis Using Data of 23 OECD Countries in the Period 1976-1996’, Small Business Economics, 24(3), 311-321.

Steinmo, Sven (1993), Democracy and Taxation, New Haven and London: Yale University Press

Storey, David J. (1994), Understanding the Small Business Sector, London: Routledge.

Swedberg, Richard (2000), Entrepreneurship: The Social Science View. Oxford: Oxford University Press.

Södersten, Jan (1984), 'Sweden', in King, Mervin A. and Don Fullerton (eds), The Taxation of Income from Capital. A Comparative Study of the United States, the United Kingdom, Sweden and West Germany, Chicago: University of Chicago Press.

Södersten, Jan (1993), 'Sweden’, in Jorgenson, Dale W. and Ralph Landau (eds), Tax Reform and the Cost of Capital. An International Comparison, Washington D.C.: Brookings.

Taylor, M. P. (2001), 'Self-Employment and Windfall Gains in Britain: Evidence from Panel Data', Economica, 68(272), 539-565.

Temple, J. (1999), 'The New Growth Evidence’, Journal of Economic Literature, 37(1), 112-156.

Utterback, J. M. and G. Reitberger (1982), ‘Technology and Industrial Innovation in Sweden: A Study of NewTechnology Based Firms’, Center for Policy Alternatives, MIT and STU, Stockholm.

Wennekers, S. and A. R. Thurik (1999), 'Linking Entrepreneurship and Economic Growth', Small Business Economics, 13(1), 27-55.

Wennekers, S., van Stel, A., Thurik, A. R. and P. D. Reynolds (2005), 'Nascent Entrepreneurship and the Level of Economic Development' Small Business Economics, 24(3), 293-309.

Werenfels Röttorp, Monica (1998), 'Den offentliga sektorns förnyelse - vad har hänt under de senaste 15 åren?', in Lundgren, Håkan, et al., På svag is, Stockholm Timbro.

Zider, B. (1998), 'How Venture Capital Works’, Harvard Business Review, November-December, 131-139. 
Figure 1 The share of total income (excluding capital gains) stemming from business income 1945-1997, for different groups in the income distribution.

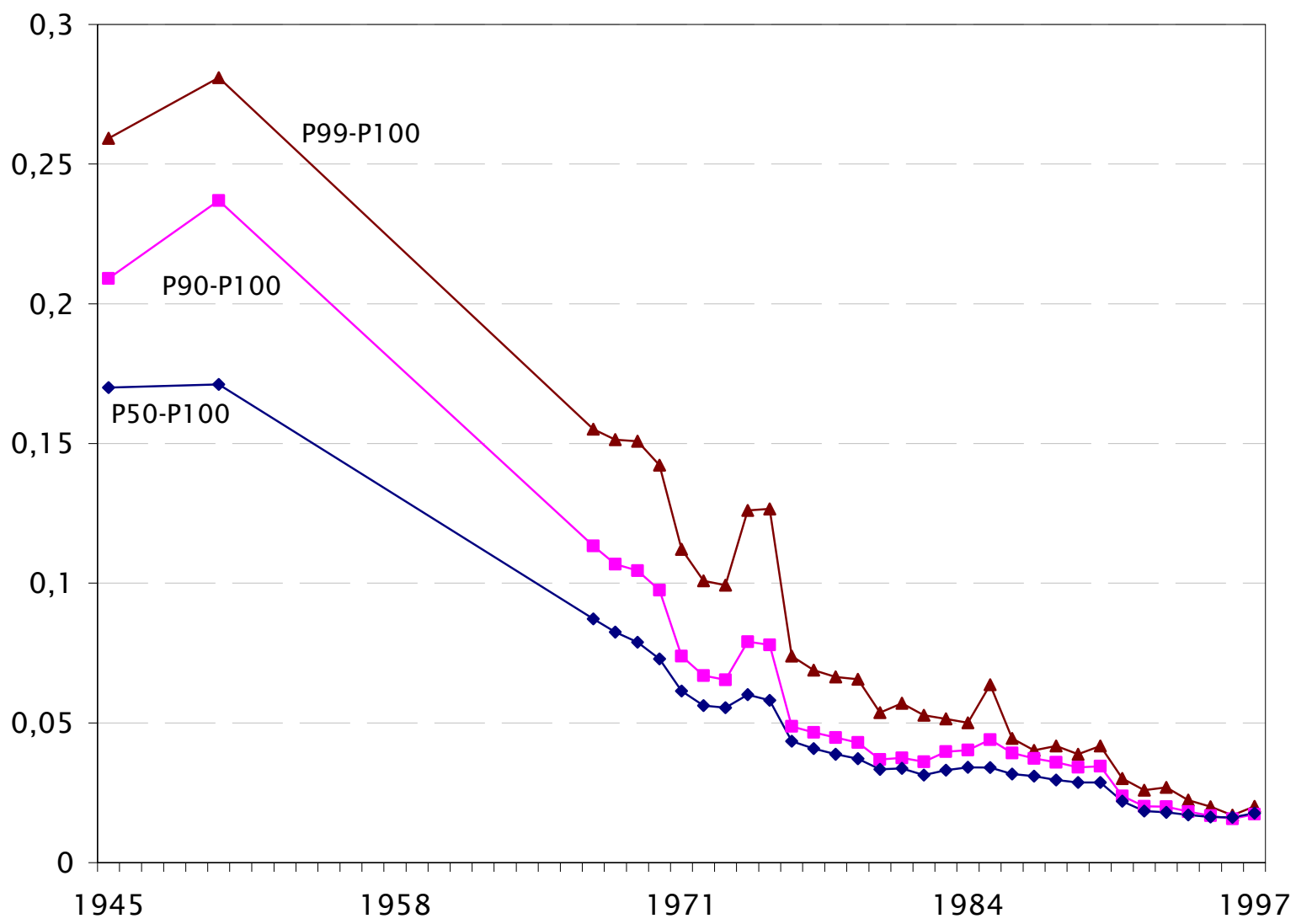

Note: Total income is the sum of wage income, capital income and business income and the figure shows the share of total income which derives from business income for the upper half of the income distribution (P50 P100), the top decile (P90-P100) and the top percentile (P99-P100) in the period 1945-1997. See Roine and Waldenström (2005) for series including capital gains and for more on the composition of income over time.

Source: Roine and Waldenström (2005). 
Figure 2. Level of Total entrepreneurial Activity in Rich OECD Countries, 2004.

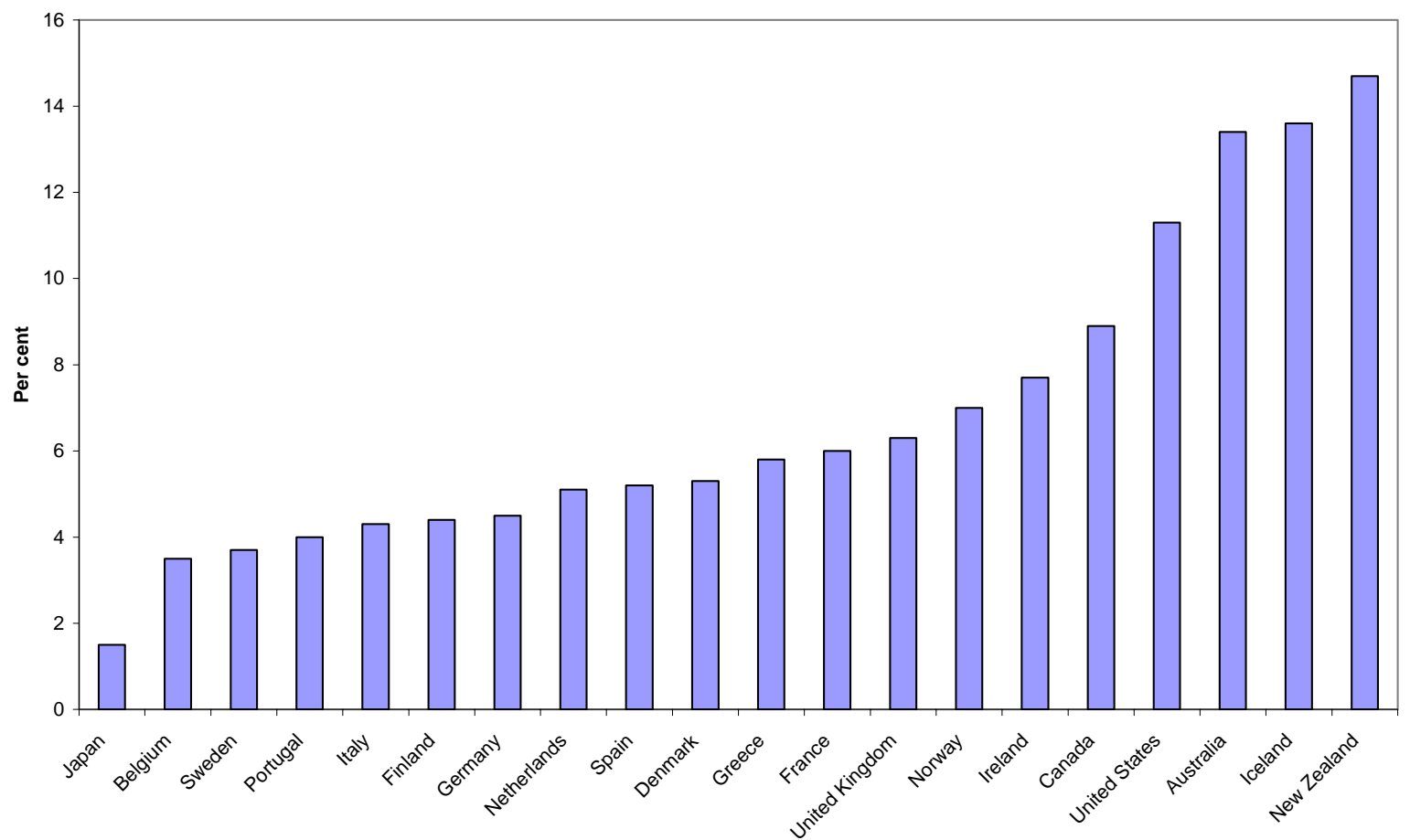

Note: The level of total entrepreneurial activity (TEA) is defined as the percentage share of the population aged 18-64 involved in either the start-up phase or managing a new business less than 42 months old. Source: Reynolds et al. (2005). 
Figure 3 Sweden’s 50 Largest Private Corporations (Turnover) - Period of Establishment.

\section{Number}

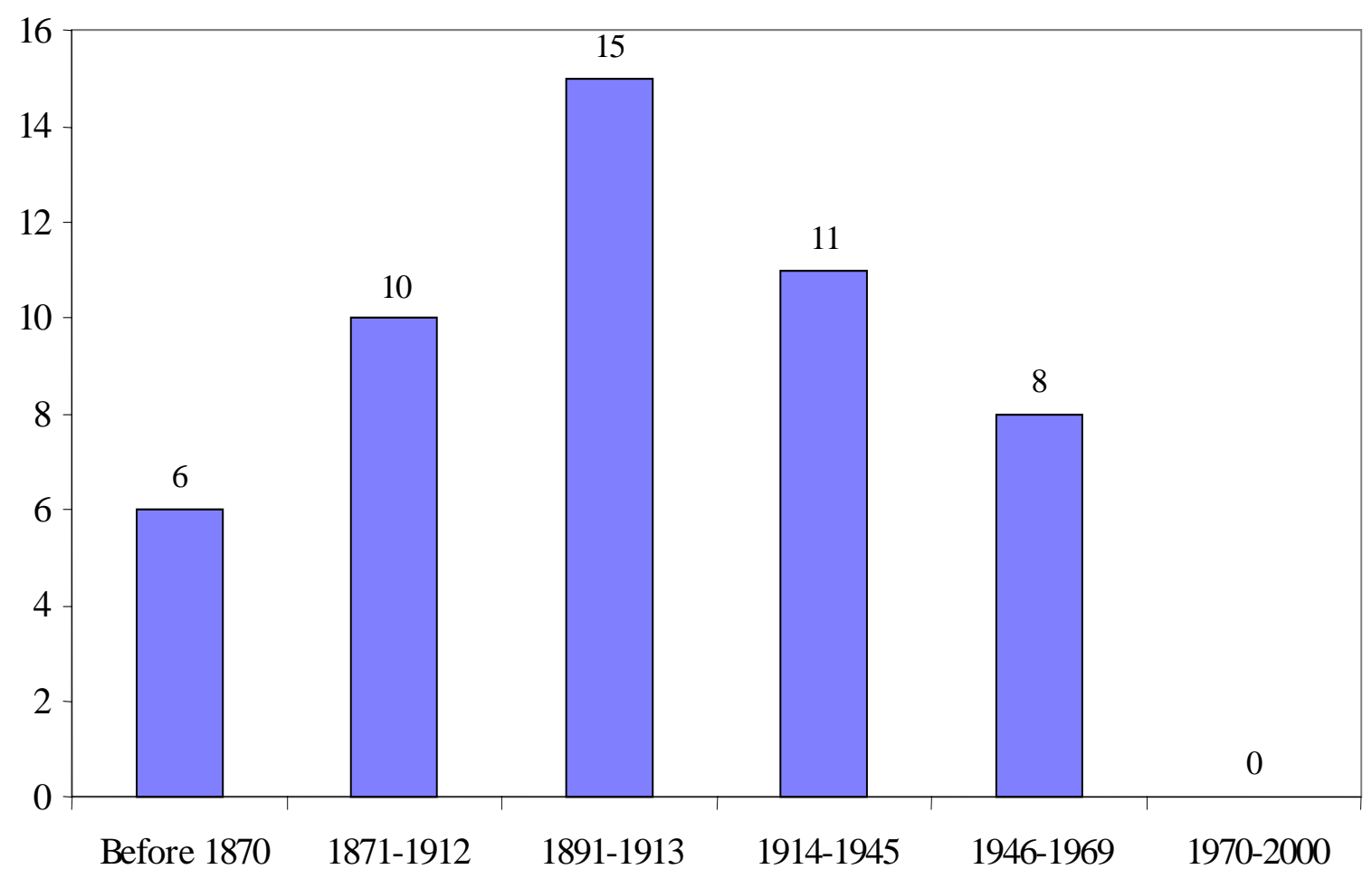

Source: NUTEK and ALMI (2001). 